\title{
Examining Post-Traumatic Stress Disorder and the Plight of Vietnam Veterans
}

\author{
Joe Stein
}

Human beings have been afflicted by the lasting mental effects of warfare for thousands of years. Over twenty-four hundred years ago, the Greek historian Herodotus wrote of a soldier at the battle of Marathon who, after witnessing the death of the soldier next to him, went completely blind, despite being "wounded in no part of his body." William Shakespeare, too, saw the effects of war on the minds of its survivors. After her husband's return from war in King Henry IV, Lady Percy wonders of him, "What is't that takes from thee thy stomach, pleasure, and thy golden sleep?"2 Both of these writings reference a mental disorder seemingly caused by the intense traumas of war. This disorder has gone by many different names, including shell shock, the thousand-yard stare, and war neurosis. Today, we classify this disorder as posttraumatic stress disorder, or PTSD.

Historians and other authors have long noted the existence of a cluster of symptoms that haunt veterans who have experienced an intense trauma. However, a definition of the disorder has been elusive. Renowned neurologist Michael R. Trimble described it as "a most frequent, yet clearly misunderstood

\footnotetext{
${ }^{1}$ Steve Bentley, "A Short History of PTSD: From Thermopylae to Hue Soldiers Have Always Had a Disturbing Reaction to War," The VVA Veteran, March/April 2005, accessed October 30, 2012, http://www.vva.org/archive/TheVeteran/2005_03/feature_HistoryPTSD.htm.

${ }^{2}$ William Shakespeare, "Act II Scene iii," In King Henry IV Part 1, ed. David Bevington. (Oxford: Clarendon Press, 1987), 173.
}

Colloquium for History Majors: Medicine and Health in World History. Professor Paula Michaels. Fall 2012. The University of Iowa.

Copyright $\mathbb{C} 2015$ Joe Stein 
aspect of human experience." 3 The present-day understanding of posttraumatic stress disorder far exceeds that of the past and has grown exponentially in the past half century. This new, expanding comprehension has dramatically improved the methods of treatment for American soldiers returning from war with PTSD, increased the benefits allocated to them by the government, and has improved the overall quality of life for these soldiers as a result.

But, have the treatments and benefits provided to them through congressional legislation been in accordance with the medical understanding of PTSD? Or have veterans suffered unnecessarily due to a lag on the part of the United States government? It is my intention, through this paper, to analyze the legislation of the United States Congress aimed at helping the thousands of severely mentally wounded veterans returning from the Vietnam War and assess the effectiveness of Congress's reaction. The legislation written by the United States Congress regarding veterans with PTSD, I argue, did not appropriately match the medical understanding of the disorder as it developed in the time period following the Vietnam War, and its ineffectiveness has harshly affected a generation of American veterans.

In order to examine Congress' reactiveness to the needs of Vietnam veterans returning home with PTSD, it is important to first understand of the history and origins of the disorder. Two primary historical developments from the middle of the nineteenth century through the beginning of the twentieth century led to an explosion of medical interest and research on the subject of a traumatic neurosis. The first catalyst was the outbreak of war, more specifically the First World War (1914-1918). As soldiers returned from the First World War with what is now known as PTSD, physicians sought to unravel the etiology of the disorder. The physicians assumed that because the onset of symptoms began after combat, the cause had to be a physical injury sustained during the combat. Initially, it was thought that micro-structural lesions to the central nervous system were the cause. This hypothesis then progressed to the theory that micro-lesions of the brain and, later, inhalation of carbon monoxide were the primary causes. ${ }^{4}$ Due to the undeveloped nature of the field of psychiatry at the time, physicians of this era viewed the source

\footnotetext{
${ }^{3}$ M.R. Trimble, "Post-traumatic Stress Disorder: History of a Concept," in Trauma and its Wake: The Study and Treatment of Post-Traumatic Stress Disorder, ed. C.R. Figley (New York: Brunner/Mazel, 1985), 5-13.

${ }^{4}$ Ibid., 7-8.
} 
of these symptoms in soldiers as being entirely physical and related in no way to mental health.

The second event was a movement that in many ways paved the road for the rise of modern psychiatry. Around the turn of the nineteenth century, the first asylums were established in Europe and the United States. Asylums were hospitals, effectively prisons, where mentally ill individuals were sent, often for the remainder of their lives. Over time, the notoriety of asylums' poor living conditions, lack of hygiene, overcrowding, and frequent mistreatment of patients became widely known. An initially tentative movement began in the 1920s and 1930s to deinstitutionalize patients living in asylums. This marked a huge shift in psychiatry, which now sought rehabilitation, as opposed to institutionalization, of its patients. ${ }^{5}$ The deinstitutionalization movement took off in the mid-twentieth century with the discovery of anti-psychotic drugs such as lithium salts, imipramine, iproniazid, chlorpromazine, and meprobamate. These new drugs were effective in treating bipolar disorder, depression, schizophrenia, and several anxiety disorders. With medications now available to help treat and, in certain cases, alleviate nearly all symptoms of mental illness, the movement to release people suffering from these various diseases back into society gained momentum. These drugs played a large role in bolstering the credibility of the field of psychiatry, as there now existed tangible treatment options to accompany the psychiatric therapy used in treating mentally-ill patients. ${ }^{6}$ The shift from institutionalization to rehabilitation and the creation of several effective anti-psychotic drugs laid the foundation for the development of modern psychiatric practices.

As time progressed, the world once again found itself at war. With the outbreak of World War II came a new generation of soldiers returning, again, with signs of mental neurosis caused by the traumas of warfare. Unlike previous wars, American military leaders during World War II_-and later the Korean War-viewed war neurosis as a serious issue, and the simultaneous

\footnotetext{
${ }^{5}$ Walid Fakhoury and Stefan Priebe, "Deinstitutionalization and Reinstitutionalization: Major Changes in the Provision of Mental Healthcare," Psychiatry 6, no. 8 (2007): 313-316, accessed December 4, 2012, http://www.sciencedirect.com/science/article/pii/S1476179307001085.

${ }^{6}$ Sheldon Preskorn, "CNS Drug Development: Part 1: The Early Period of CNS Drugs," Journal of Psychiatric Practice 16, no. 5 (2010): 334-339, accessed December 4, 2012, http://ovidsp.tx.ovid.com/sp3.7.1b/ovidweb.cgi? $T=J S \& P A G E=$ fulltext $\& D=$ ovft $\& A N=00131746-201009000-$ $00006 \& N E W S=N \& C S C=Y \& C H A N N E L=$ PubMed .
} 
shifts and developments in psychiatry supported this conclusion. As a result, they ordered military psychiatrists, like Abram Kardiner, to study soldiers suffering from traumatic neuroses. ${ }^{7}$ The increase in the number of psychiatric studies as a result of World War II led psychiatrists around the world to agree that a standardized manual of diagnostics and treatment was now necessary. ${ }^{8}$

In 1952, the American Psychiatric Association (APA) released what was to become the standard desk reference book of psychiatrists, a book to which the diagnosis of all mental disorders would adhere. This book was the APA's Diagnostic and Statistics Manual of Mental Disorders, the first edition of which was commonly known as the DSM-I. The DSM-I drew heavily from the works of military psychiatrists like Kardiner and included among its entries "gross stress reaction." Gross stress reaction, according to the DSM-I, is a temporary mental disturbance caused by extreme environmental stress, often occurring in patients with no previous signs of a mental health problem. ${ }^{10}$ This disorder, however, was not listed as either a mental neurosis or psychosis due to the fact that it was perceived to be merely temporary, and removal from the stressful situation was thought to rapidly cure a patient. ${ }^{11}$ The DSM-I remained the ultimate authority on any trauma induced mental condition until several years after the beginning of the Vietnam War.

The United States first committed ground troops to Vietnam in 1965, several months after the APA had begun working on the second edition of its Diagnostics and Statistics Manual, known as the DSM-II. Unlike World War II and the Korean War, psychiatric casualties at the beginning of the Vietnam War were extremely low, twenty percent lower than the peak of psychiatric casualties during the Korean War. This was believed to be caused by an updated and renovated practice known as the Salmon program which placed a psychiatrist within every battalion stationed in a Vietnam combat zone. This

${ }^{7}$ Wilbur J. Scott, "PTSD in DSM-III: A Case in the Politics of Diagnosis and Disease," Social Problems 37, no. 3 (August 1990): 295, accessed October 16, 2012 , http:/ / www.heinonline.org.proxy.lib.uiowa.edu/HOL/Page?page $=294 \&$ handle $=\mathrm{h}$ ein.journals $\% 2$ Fsoc prob37\&collection=journals \#309.

${ }^{8}$ Nancy C. Andreasen, "Posttraumatic Stress Disorder: A History and a Critique," Brainline.org, October 1, 2010, accessed April 30, 2015, http://www.brainline.org/content/2011/01/posttraumatic-stress-disorder-ahistory-and-a-critique_pageall.html.

9 Scott, "PTSD in DSM-III," 295.

${ }^{10}$ Diagnostic and Statistical Manual of Mental Disorders: DSM-I (Washington, D.C.: American Psychiatric Association,1952), 40.

${ }^{11}$ Scott, "PTSD in DSM-III," 295. 
practice dropped rates of psychiatric casualties to below five out of every thousand soldiers. ${ }^{12}$ It appeared that military psychiatrists had solved the problem. As a result of these numbers, when the DSM-II was published in 1968, gross stress reaction was omitted. In fact, the DSM-II made no mention of any trauma induced mental disorder.

But as soldiers returned home from Vietnam, they too began to suffer the same effects that had plagued American veterans for generations. They showed all the typical symptoms of war neurosis: difficulty sleeping, an overly sensitive reaction to stimuli, flashbacks, and sensory dulling through substance abuse. The nomenclature of the DSM-II — used by psychiatrists, insurance companies, hospitals, and the court system to assess mental illness - made no mention of a war neurosis. As a result, veterans were often considered delusional and their flashbacks considered sensory-triggered hallucinations. These assumptions, more often than not, led to a misdiagnosis of paranoid schizophrenia and psychomotor epilepsy. Unfortunately, these symptoms were also typical among people addicted to lysergic acid diethylamide (LSD), a recreational psychedelic drug gaining popularity throughout the late 1960s. Due to this, veterans were often also misdiagnosed as LSD addicts, contributing to the already large number of misdiagnosed cases of PTSD. ${ }^{13}$

These misdiagnoses proved to be very detrimental to veterans returning home for two simple reasons. In the first instance of a veteran being misdiagnosed with either schizophrenia or epilepsy, the veteran could not qualify for treatment from the Veteran's Administration (VA), because these disorders would be considered pre-existing conditions. Since these conditions were regarded as existing before combat and thus not caused by combat experience itself-however much combat may have exacerbated these conditions - the VA was not responsible for providing medical treatment for the veteran. In the second instance of the misdiagnosis of LSD abuse, the veteran would also be refused medical service. It was not until the passage of the Veteran's Omnibus Health Care Act of 1976 that veterans with a substance use disorder (SUD) were allowed to enter rehabilitation under the coverage of

12 Ibid., 297.

13 Theodore Van Putten and Warden H. Emroy, "Traumatic Neuroses in Vietnam Returnees: A Forgotten Diagnosis?”, Arch Gen Psychiatry 29 (November 1973): 69598, accessed October 16, 2012, doi:10.1001/archpsyc.1973.04200050100017. 
the VA. ${ }^{14}$ In any case, the simple fact remained that, as VA psychiatrist and future Chief of VA Psychiatric Services Arthur Blank would later put it, "Most American psychiatrists...based their encounters with Viet Nam veterans on the official view that no such thing as PTSD existed," and viewed the veterans as "dysfunctional and bizarre."15

While the United States continued and escalated its war efforts in Vietnam, more soldiers returned home bearing the mental scars of what they had experienced on the battlefield. When describing what war was like, Sonny Hartwell, a Vietnam veteran with PTSD, remembered the constant uncertainty and dangers he experienced: "War is a strange thing. You spend so much time with nothing to do and the boredoms of every day existence [sic] in a camp-like setting and then all hell breaks loose. That might last for just a few seconds, but the terror and trauma that you go through in just that minute to few seconds can be mind boggling." 16 To an unprecedented degree, these scars made it extremely difficult for veterans to re-assimilate back into the American public. Amplified by the growing anti-war sentiment at home, veteran Lou Schembri recalled the difficulties of coming home, remarking, "For the first twenty-five or thirty years I guess I didn't really take much notice of what it was, I didn't know what it was called or anything. It was just a matter of: always angry; always drinking; couldn't hold down a job. It was years later I was told: 'You have PTSD."'17

Mr. Schembri is by no means an isolated case, and the influx of returning veterans like him eventually caught the attention of Senator Alan Cranston (DCA). A progressive Senator and a champion of veterans' rights, Cranston's

${ }^{14}$ Library of Congress, "Bill Summary \& Status - 94th Congress (1975 - 1976) S.2908 - CRS Summary," THOMAS (Library of Congress), accessed October 16, 2012, http://thomas.loc.gov/cgibin/bdquery/z?d094:SN02908:@@@D\&umm2=m\&.

15 Stephen M. Sonnenberg and Arthur S. Blank, "Irrational Responses to PostTraumatic Stress Disorder and Viet Nam Veterans," in The Trauma of War: Stress and Recovery in Viet Nam Veterans, ed. Stephan M. Sonnenberg, Arthur S. Blank, and John A. Talbott (Washington, D.C.: American Psychiatric Press, 1985), 73-74.

16 Sonny Hartwell, interview by Jim Fazio, “American Warrior Radio with Sonny Hartwell Vietnam Veteran Interview” (video), American Warrior Radio, January 8, 2012, accessed December 4, 2012, https://www.youtube.com/watch?v=PLNMNKOm88U

${ }^{17}$ Lou Schembri, interview by Justin Stankovic, "Vietnam Veteran Interview” (video), RMIT University, May 26,2011, accessed December 4, 2012, http://www.youtube.com/watch?v=SMyg0OwIGUg. 
investigation into the prevalence of PTSD in returning veterans led to a hearing before the Senate Committee on Veterans Affairs on January 27, 1970. This hearing, an examination of "the psychological predicament of the Vietnam veteran," was the first Congressional action of any sort towards addressing this "predicament."18

Psychiatrist Robert Jay Lifton, an ardent opponent to the Vietnam War, was among those testifying before the Senate Committee. A veteran of the Korean War, Dr. Lifton described the intense confusion and terror that became part of a soldier's everyday life in a counterinsurgency war like Vietnam. He described how the horrors of warfare created an "advanced state of psychic numbing" to images of death and destruction, and even actions of "general brutalization." In the American G.I., he said, this creates the "impulse toward revenge, toward overcoming his own emotional conflicts and giving meaning to his buddies' sacrifice by getting back at the enemy." ${ }^{19}$ Despite the fact that many soldiers had returned home, Lifton concluded, it was still immensely difficult for many of these veterans to leave the war behind, psychologically speaking. Without an enemy to fight any longer, and ushered back into a society that increasingly viewed their own and their buddies' sacrifices as criminal, the homebound veteran was left to cope with these feelings alone.

With Dr. Lifton's powerful words still ringing in the ears of Senators charged with protecting the well-being of American veterans, a new policy to address the psychological trauma experienced by Vietnam veterans, or at least some modicum of reform, seemed imminent. Unfortunately, not only was such reform in truth not imminent, but it was still many years to come. Could it be that a trauma induced neurosis could not, and did not, exist? We now know this could not be farther from the truth, but it would be another decade before the American Psychiatric Association definitively answered this question, and even longer before the Senate would act.

The following year, the issue of mental health in regard to Vietnam veterans was brought into the national spotlight. On April 30, 1971, a Detroit storeowner shot and killed a man attempting to rob his store. Normally, such an event would not attract national press. But in this instance, the robber was

\footnotetext{
${ }^{18}$ Robert J. Lifton, Witness to an Extreme Century: A Memoir (New York: Free Press, 2011), 176.

${ }^{19}$ Ibid., 176.
} 
Sergeant Dwight "Skip" H. Howard, a veteran who had the Congressional Medal of Honor placed around his neck by President Lyndon Johnson only two short years prior to his death. In November of the previous year, Howard had been diagnosed by military psychiatrists as having "depression caused by post-Vietnam adjustment problems." 20 According to psychiatrists, Howard had been haunted by the memory of a face-to-face encounter with a North Vietnamese soldier who he killed in close quarters combat. Howard suffered from severe neurosis and was unable to hold down a job, quickly developing alcohol dependence upon his return stateside. The grocery storeowner, while giving his account of the robbery, told the Detroit Police: "I first hit him with two bullets, but he just stood there, with the gun in his hand and said, 'I'm going to kill you...' I kept pulling the trigger until my gun was empty."21 Throughout the attempted robbery, Howard, an experienced combat veteran, did not fire his weapon once. Howard's mother, after her son's death, stated: "Sometimes I wonder if Skip tired of this life and needed someone else to pull the trigger." 22

In response to Sergeant Howard's death, noted Polish-born psychiatrist Chaim Shatan published an essay on May 6, 1972 in The New York. Times titled "Post-Vietnam Syndrome." In the article, he described the psychological symptoms that many Vietnam veterans experienced, including guilt, rage, and a sense of alienation from one's own feelings and society. The most severe and detrimental symptom was a victim doubting his ability to ever feel love for another person again, and rejecting the affection of others. In the article, Shatan quoted veterans suffering from this post-Vietnam syndrome as saying, "You paid a high price for trusting other people in the Nam. Every time you acted human, you got screwed." He quoted another as remarking, "I hope I can learn to love as much as I learned to hate—and I sure hated, man." ${ }^{23}$ In the aftermath of his article, Shatan claimed that his phone was ringing off the hook with veterans and veteran support groups seeking further insight into the disorder. ${ }^{24}$

In addition to his controversial and eye-opening op-ed piece, Shatan published several other essays on post-Vietnam syndrome. He described its

20 "Sgt. Dwight H. Howard: Medal of Honor Recipient," Iron Worth Productions, accessed November 9, 2012,

${ }^{21}$ Idem.

http://ironworthproductions.com/resources/Dwight+Johnson+Info.pdf.

${ }^{22}$ Idem.

${ }^{23}$ Chaim F. Shatan, "Post-Vietnam Syndrome," New York Times, May 6, 1972, 35.

${ }^{24}$ Wilbur, "PTSD in DSM-III", 301. 
source as unconsummated grief, in which "an encapsulated, never ending past deprives the present of meaning." 25 Even after the tragic death of Sergeant Howard and the insight provided by Shatan into the minds of these wounded warriors, Congress failed to make mental health issues among Vietnam veterans a priority for several years.

In 1976, a small victory was won in the plight of the afflicted soldier. Congress, after a series of studies relating to alcoholism and drug abuse rates among returning veterans, passed the Veteran's Omnibus Health Care Act of 1976. This act, for the first time, guaranteed that a veteran could not be refused medical services by the VA due to substance use dependence-i.e. an addiction to alcohol or other drugs. This landmark bill also allocated funds towards mental health research and, for the first time, established criteria under which veterans could become eligible for mental health services through the VA, after being evaluated by a VA psychiatrist. ${ }^{26}$

At the time of the passing of the new law in 1976, the American Psychiatric Association was already developing the new DSM-III. According to Dr. Robert Spitzer, the head of the APA's Task Force on Nomenclature-the group responsible for compiling the new manual_-"no change [was] planned" in regard to the standing of war neurosis in the third edition. ${ }^{27}$ This news caught psychiatrists such as Robert Lifton and Chaim Shatan by surprise, as they had thought that their work to raise public awareness on psychological trauma experienced by veterans had been effective. It was not until January 1978, however, that their work was truly rewarded. After a presentation to the APA's Committee on Reactive Disorders on the results of over seven hundred case studies of veterans suffering from war neurosis, Lifton and Shatan succeeded in adding the newly coined diagnosis "post-traumatic stress disorder" to the DSM-III. ${ }^{28}$

In 1979, the year before the DSM-III was released, Senator Alan Cranston finally saw the passage of a bill he had first sponsored eight years earlier. With news of significant changes being made in the new version of the diagnostic manual and more research coming to light in support of these changes, Congress began to act. First introduced in 1971, the year after Senator Cranston

${ }^{25}$ Chaim F. Shatan, "The Grief of Soldiers in Mourning: Vietnam Combat Veterans' Self Help Movement," American Journal of Orthopsychiatry 43 (1973): 648.

26 "Bill Summary \& Status - 94th Congress (1975 - 1976) - S.2908."

${ }^{27}$ Wilbur, "PTSD in DSM-III," 298.

28 Ibid., 304-307.

http://ir.uiowa.edu/iowa-historical-review 
had heard Dr. Lifton's testimony, the Veteran's Health Care Amendments Act of 1979 was a step in the right direction. This bill provided for "a program of readjustment counseling for any veteran who served on active duty during the Vietnam era who requests such counseling within two years from discharge."29 It also expanded on the VA's program to help treat and rehabilitate veterans with substance dependencies. ${ }^{30}$ Both of these new programs would have proved beneficial to soldiers suffering from PTSD, but Congress overlooked a key aspect of Shatan's research. In his essays on post-Vietnam syndrome, he noted through interviews with veterans as well as his own observations that symptoms of PTSD usually did not manifest until between nine and thirty months after the soldier had returned from Vietnam. ${ }^{31}$ Given the delayed onset of the symptoms, Congress' limitation on readjustment counseling being available only to veterans within two years of discharge, and the still quite limited knowledge of the disorder, this bill represented only a small improvement for veterans.

Later that same year, just months before the release of the DSM-III, Congress passed the Veterans' Health Program Extension and Improvement Act of 1979, which helped to emphasize the importance of mental health care for veterans. With the field of psychiatry gradually gaining even more credibility, this act dramatically expanded the role of psychiatry within the VA. This bill now allowed psychiatrists to be eligible for appointment to positions within the VA's Department of Medicine and Surgery, which guides the medical policies of the VA. ${ }^{32}$ The incorporation of psychiatrists into this department helped emphasize the issue of the prevalence of mental health disorders amongst Vietnam veterans.

In the wake of the publishing of the DSM-III, no major legislation was passed expanding the treatment of PTSD. Despite the increase in

29 “Veteran's Health Care Amendments Act of 1979”, Pub. L. No. 96-22, 96 ${ }^{\text {th }}$ Cong., $7^{\text {th }}$ Session (June 13, 1979).

${ }^{30}$ Library of Congress, "Bill Summary \& Status - 96th Congress (1979 - 1980) - S.7 CRS Summary," THOMAS (Library of Congress), accessed October 16, 2012, http://thomas.loc.gov/cgibin/bdquery/z?d096:SN00007:@@@D\&summ2=m\&.

${ }^{31}$ Shatan, "The Grief of Soldiers in Mourning," 648.

${ }^{32}$ Library of Congress, "Bill Summary \& Status 96th Congress (1979 - 1980) H.R.3892 CRS Summary," THOMAS (Library of Congress), accessed October 16, 2012, thomas.loc.gov/cgibin/bdquery/D?d096:1:/temp/ bdHEYN:@@@\&summ2=m\&|/home/Legi slativeData.php?n=BSS;c=96|. 
congressional funding and the many case studies and research projects conducted concerning PTSD in Vietnam veterans, some of which projected the prevalence of PTSD amongst all veterans to be over twenty percent, no significant legislation was passed by Congress until 1983. ${ }^{33}$ With the passage of the Veterans' Health Care Amendments Act of 1983, three full years after the release of the DSM-III, Congress finally took real action on behalf of veterans with PTSD. This law provided free readjustment counseling in the form of general mental or psychiatric counseling to any Vietnam veteran seeking it. It also allocated millions of dollars for PTSD research over the next several years. ${ }^{34}$

In the year following this significant Act, the Veterans' Health Care Act of 1984 was signed into law, establishing the long needed institutions necessary to bolster the research and treatment of post-traumatic stress disorder. With the appropriation of new funds, the Chief Medical Director of the VA created specialized programs for the diagnosis and treatment of PTSD, including the Special Committee on PTSD within the VA. It also provided funds for the construction and operation of a National Center on PTSD as a research, training, and resource center for information concerning the diagnosis and treatment of PTSD. ${ }^{35}$

It was nearly two decades after United States military involvement in Vietnam began before significant legislation was passed on behalf of the thousands of troops returning with the mental scars that only a brutal, dehumanizing war like that in Vietnam could produce to such an extensive degree. As a part of the Veterans' Health Care Amendments Act of 1983, the VA conducted the National Vietnam Veterans Readjustment Study.

${ }^{33}$ Robin LaDue. "The Assessment of Post-Traumatic Stress Disorder among Minority Vietnam Veterans" (lecture, Minority Assessment Conference, Tucson, AZ, November 1, 1983); Christine Scott, "Veterans' Affairs: Historical Budget Authority, FY1940-FY2012,” Congressional Research Services 7-5700 (2012): 4.

${ }^{34}$ Library of Congress, "Bill Summary \& Status - 98 $8^{\text {th }}$ Congress (1983 - 1984) H.R.2920 - CRS Summary," THOMAS (Library of Congress), accessed October 16, 2012, http://thomas.loc.gov/cgibin/bdquery/D?d098:2:./temp/ bdebjL:@@@D\&umm2=m\&|/home/Legisla tiveData.php?n=BSS;c=98.

${ }^{35}$ Library of Congress, "Bill Summary \& Status $-98^{\text {th }}$ Congress $(1983-1984)-$ H.R.5618 - CRS Summary," THOMAS (Library of Congress), accessed October 16, 2012, http:/ / thomas.loc.gov/cgibin/bdquery/D?d098:3:./temp/ bd3ATO:@@@D\&summ2=m\&|/home/Legi slativeData.php?n=BSS;c $=98$. 
Completed in 1988, the study highlighted the lasting effects of PTSD on Vietnam veterans. At the time of the study, approximately 830,000 veterans had reported symptoms and related functional impairment associated with PTSD. This number constituted twenty-six percent of all Vietnam era veterans, and revealed the extent to which veterans affected by PTSD exceeded earlier projections. The study also revealed extremely high rates of alcohol and drug dependence, depression, anxiety disorders, and antisocial personality disorder stemming from PTSD. ${ }^{36}$

In addition to these comorbid psychological issues associated with PTSD, the response of the United States government to the overwhelming number of veterans with PTSD created an overall distrust of government agencies amongst a broad cross-section of veterans, not just those suffering from PTSD. ${ }^{37}$ This distrust contributed to many veterans refusing medical services from the VA as well as other health institutions, and led many veterans to ignore the obvious fact that their mental health and stability had been adversely affected by the things they did and saw during their active duty. This distrust harbored by many veterans has lingered for many years, and recent data suggests that Vietnam veterans, as they have entered their later years of life, have begun to flock to VA medical facilities for health issues that arose four decades ago. ${ }^{38}$ The cause of this influx is unknown, although it may be related to new developments in PTSD treatment. Recent studies have made great strides in treating chronic PTSD. A recent British study has provided evidence that sensory therapy, designed to foster appropriate neurological responses to stimuli, takes priority over emotional therapy, which attempts to resolve painful or unbearable memories. Due to this, sensory therapy has proven to be crucial in the alleviation of PTSD symptoms. ${ }^{39}$ The VA reports that nearly one

${ }^{36}$ Jennifer Price, "Findings from the National Vietnam Veterans' Readjustment Study," National Center for PTSD, accessed November 11, 2012, http://www.ptsd.va.gov/professional/pages/vietnam-vets-study.asp.

${ }^{37}$ Bob Filner, "VA Health Care: Status of VA's Approach in Conducting the National Vietnam Veterans Longitudinal Study," United States Government Accountability Office, accessed November 12, 2012, www.gao.gov/assets/100/96710.pdf.

38 Maura Lerner, "Vietnam Veterans Getting Old, Getting Sick," PTSD Support Services, accessed November 11, 2012, http://www.ptsdsupport.net/Vietnam_Veterans_Getting_Old_Getting_Sick.html.

39 Jonathan Bisson et al., "Psychological Treatments for Chronic PTSD," British Journal of Psychiatry 190 (2007): 97-104, accessed December 4, 2012, doi: 10.1192/bjp.bp.106.021402. 
hundred thousand new Vietnam veterans were added to its disability rolls in 2007 alone. ${ }^{40}$

The culmination of the high rates of PTSD and other psychological disorders, the delayed response from the government, and the general distrust of government agencies can be seen in the frighteningly high rates of homelessness among Vietnam veterans. There are an estimated two hundred thousand homeless veterans in the United States, the vast majority of whom are Vietnam veterans. ${ }^{41}$ The issue of homelessness among veterans has been a serious domestic issue for a great deal of time and should be considered a blemish on American society.

The treatment of American veterans after Vietnam is a black mark on our nation's record and has been described by prominent public figures such as President Obama as "disgraceful." 42 Furthermore, veterans returning home with post-traumatic stress disorder were even more debilitated than their counterparts who were unaffected by the disorder. For years, these brave soldiers suffered in silence, unrecognized by diagnostic medicine, unable to be helped by their loved ones, and left to fend for themselves by the same government that sent them to war. Congressional legislation and policy towards Vietnam veterans with PTSD did not reflect the evolving medical understanding of the condition at the time, and the lack of action on the part of the U.S. government left an enormous portion of an entire generation of American veterans broken, sick, and distrustful of their government. These brave men were willing to sacrifice everything, and they were repaid with dishonor and abandonment. It is because of their struggle and ongoing suffering that future veterans will, with hope, never experience what they went through and will receive the care and respect they have earned through their sacrifice for their country.

${ }^{40}$ Lerner, "Vietnam Veterans Getting Old, Getting Sick."

${ }^{41}$ Mike Mount, "Homeless veterans face new battle for survival," CNN, July 2, 2008, accessed November 11, 2012, http:/ /articles.cnn.com/2008-07-

02/us/homeless.veterans_1_homeless-veterans-vietnam-veterans-veteransaffairs?_s=PM:US.

42 Raf Sanchez, "Barack Obama condemns America's treatment of Vietnam veterans as 'national shame,"' -The Telegraph, May 28, 2012, accessed November 12, 2012, http://www.telegraph.co.uk/news/worldnews/barackobama/9296485/BarackObama-condemns-Americas-treatment-of-Vietnam-veterans-as-nationalshame.html. 


\section{Bibliography}

Andreasen, Nancy C. "Posttraumatic Stress Disorder: A History and a Critique." Brainline.org. Accessed April 15, 2015.

http://www.brainline.org/content/2011/01/posttraumatic-stress-disorder-ahistory-and-a-critique_pageall.html.

Bentley, Steve. "A Short History of PTSD: From Thermopylae to Hue Soldiers Have Always Had a Disturbing Reaction to War." The VVA Veteran, March/April 2005. Accessed October 30, 2012.

http://www.vva.org/archive/TheVeteran/2005_03/feature_HistoryPTSD.htm.

Bisson, Jonathan, Anke Ehlers, Rosa Matthews, Stephen Pilling, David Richards, and Stuart Turner. "Psychological Treatments for Chronic PTSD." British Journal of Psychiatry 190 (2007): 97-104. Accessed December 4, 2012. doi: 10.1192/bjp.bp.106.021402.

Diagnostic and Statistical Manual of Mental Disorders: DSM-I. Washington D.C.: American Psychiatric Association, 1952.

Fakhoury, Walid, and Stefan Priebe. "Deinstitutionalization and Reinstitutionalization: Major Changes in the Provision of Mental Healthcare." Psychiatry 6, no. 8 (2007): 313-316. Accessed December 4, 2012. http://www.sciencedirect.com/science/article/pii/S1476179307001085.

Filner, Bob. "VA Health Care: Status of VA's Approach in Conducting the National Vietnam Veterans Longitudinal Study." United States Government Accountability Office. Accessed November 12, 2012. www.gao.gov/assets/100/96710.pdf.

LaDue, Robin. "The Assessment of Post-Traumatic Stress Disorder among Minority Vietnam Veterans." Lecture at the Minority Assessment Conference, Tucson, AZ, November 1, 1983.

Lerner, Maura. "Vietnam Veterans Getting Old, Getting Sick." PTSD Support and Services. Accessed November 11, 2012.

http://www.ptsdsupport.net/Vietnam_Veterans_Getting_Old_Getting_Sick.ht $\mathrm{ml}$.

Library of Congress. "Bill Summary \& Status - 94th Congress (1975 - 1976) - S.2908 CRS Summary.” THOMAS (Library of Congress). Accessed October 16, 2012. http://thomas.loc.gov/cgibin/bdquery/z?d094:SN02908:@@@\&summ2=m\&.

Library of Congress. "Bill Summary \& Status 96th Congress (1979 - 1980) H.R.3892 CRS Summary." THOMAS (Library of Congress). Accessed October 16, 2012. thomas.loc.gov/cgibin/bdquery/D?d096:1:./temp/ bdHEYN:@@@\&summ2=m\&|/home/Le gislativeData.php? $\mathrm{n}=\mathrm{BSS} ; \mathrm{c}=96$.

Library of Congress. "Bill Summary \& Status - 96th Congress (1979 - 1980) - S.7 CRS Summary.” 'THOMAS (Library of Congress). Accessed October 16, 2012. 
http://thomas.loc.gov/cgi-

bin/bdquery/z?d096:SN00007:@@@D\&summ2=m\&.

Library of Congress. "Bill Summary \& Status - 98 ${ }^{\text {th }}$ Congress (1983 - 1984) -

H.R.2920 - CRS Summary." THOMAS (Library of Congress). Accessed October 16, 2012. http://thomas.loc.gov/cgi-

bin/bdquery/D?d098:2:./temp/ bdebjL:@@@D\&summ2=m\&|/home/Legisl ativeData.php? $\mathrm{n}=\mathrm{BSS} ; \mathrm{c}=98$.

Lifton, Robert Jay. Witness to an Extreme Century: A Memoir. New York: Free Press, 2011.

Lou Schembri. "Vietnam Veteran Interview.” By Justin Stankovic. YouTube.

Accessed December 4, 2012.

http://www.youtube.com/watch?v=SMyg0OwIGUg.

Mount, Mike. "Homeless veterans face new battle for survival." CNN, July 2, 2008.

Accessed November 11, 2012. http:/ / articles.cnn.com/2008-07-

02/us/homeless.veterans_1_homeless-veterans-vietnam-veterans-veteransaffairs?_s=PM:US.

Preskorn, Sheldon. "CNS Drug Development: Part 1: The Early Period of CNS Drugs." Journal of Psychiatric Practice 16, no. 5 (2010): 334-339. Accessed December 4, 2012.

http://ovidsp.tx.ovid.com/sp3.7.1b/ovidweb.cgi? $T=J S \& P A G E=$ fulltext\&D=ov $\mathrm{ft} \& \mathrm{AN}=00131746-201009000$ -

$00006 \& N E W S=$ N\&CSC $=$ Y\&CHANNEL $=$ PubMed 0 .

Price, Jennifer. "Findings from the National Vietnam Veterans' Readjustment Study." National Center for PTSD. Accessed November 11, 2012.

http://www.ptsd.va.gov/professional/pages/vietnam-vets-study.asp

Sanchez, Raf. "Barack Obama condemns America's treatment of Vietnam veterans as 'national shame." The Telegraph, May 28, 2012. Accessed November 12, 2012.

http://www.telegraph.co.uk/news/worldnews/barackobama/9296485/BarackObama-condemns-Americas-treatment-of-Vietnam-veterans-as-nationalshame.html.

Scott, Christine. "Veterans' Affairs: Historical Budget Authority, FY1940-FY2012." Congressional Research Services 7-5700 (2012): 1-6.

Scott, Wilbur J. "PTSD in DSM-III: A Case in the Politics of Diagnosis and Disease." Social Problems 37, no. 3 (August 1990): 294-310. Accessed October 16, 2012. http://www.heinonline.org.proxy.lib.uiowa.edu/HOL/Page?page $=294 \&$ handle $=$ hein.journals $\% 2$ Fsoc prob37\&collection=journals \#309.

"Sgt. Dwight H. Johnson: Medal of Honor Recipient.” Iron Works Productions. Accessed November 9, 2012.

http://ironworthproductions.com/resources/Dwight+Johnson+Info.pdf.

Shakespeare, William. "Act II Scene iii." In King Henry IV part 1, edited by David Bevington, 172-177. Oxford: Clarendon Press. 1987. 
Shatan, Chaim F. "Post-Vietnam Syndrome." New York Times, May 6, 1972.

Shatan, Chaim F. "The Grief of Soldiers in Mourning: Vietnam Combat Veterans' Self Help Movement." American Journal of Orthopsychiatry 43 (1973): 640-653.

Sonnenberg, Stephen M., and Arthur S. Blank. "Irrational Responses to Post-

Traumatic Stress Disorder and Viet Nam Veterans." In The Trauma of War: Stress and Recovery in Viet Nam Veterans, edited by Stephan M. Sonnenberg, Arthur S. Blank, John A. Talbott, 71-98. Washington, D.C.: American Psychiatric Press, 1985.

Sonny Hartwell. "American Warrior Radio with Sonny Hartwell Vietnam Veteran Interview.” By Justin Stankovic. YouTube. American Warrior Radio. January 8, 2012. accessed December 4, 2012, http://www.youtube.com/watch?v=PLNMNKOm88U.

Trimble, M.R. "Post-traumatic Stress Disorder: History of a Concept.” In Trauma and its wake: The Study and Treatment of Post-Traumatic Stress Disorder, edited by C.R. Figley, 5-13. New York: Brunner/Mazel, 1985.

Van Putten, Theodore, and Warden H. Emroy. "Traumatic Neuroses in Vietnam Returnees: A Forgotten Diagnosis?” Arch Gen Psychiatry 29 (November 1973): 695-8. Accessed October 16, 2012. doi:10.1001/archpsyc.1973.04200050100017.

“Veteran's Health Care Amendments Act of 1979." Pub. L. No. 96-22, 96 $6^{\text {th }}$ Cong., $7^{\text {th }}$ Session (June 13, 1979). US Government Publishing Office. http://www.gpo.gov/fdsys/pkg/STATUTE-93/pdf/STATUTE-93-Pg47.pdf. 